\title{
Clasificación de los revoques multiestratificados del claustro de S. Abbondio en Como (Italia): un instrumento analítico para la arqueología de la arquitectura
}

\section{Classification of multi-layered plaster in St. Abbondio Cloister at Como, Italy: an analytical tool for architectural archaeology}

\author{
R. Bugini(*), S. Della Torre(**), A. Pozzi(***), L. Rampazzi(***), A. Sansonetti( ${ }^{(*)}$ \\ Recepción/Received: 25-IV-05 \\ Aceptación/Accepted: 1-II-06
}

\section{RESUMEN}

S. Abbondio (Como, Italia) es una de las mas extraordinarias basílicas románicas presentes en el norte de Italia. El edificio entero y en particular el claustro ha sido expuesto a varias intervenciones durante los ultimos siglos, en particular los últimos trabajos de conservación ejecutados entre los años 2000 y 2003. En esta ocasión se ha efectuado una vasta campaña diagnóstica sobre los revoques tanto internos como externos, destinada a clasificarlos desde el punto de vista compositivo-morfológico y para descubrir la historia sobre la conservación del claustro. Revoques representativos de las diferentes fases constructivas han sido identificados con la utilización de métodos como el análisis de difracción de rayos $\mathrm{X}$ en polvo, porosimetría por intrusión de mercurio, microscopía óptica para secciones finas y espectrometría atómica. Los resultados han permitido agrupar las muestras que presentaban características similares, confirmando hipótesis históricas sobre la secuencia de las intervenciones en el edificio, sugiriendo un método analítico que podría ser usado como un instrumento válido en caso de estudios sobre la arqueología de la arquitectura.

Palabras clave: clasificación de los revoques, arqueología de la arquitectura, claustro de S. Abbondio (Como), revoques históricos.

\section{SUMMARY}

St. Abbondio, at Como, Italy, is one of the most outstanding Romanesque basilicas in Northern Italy. The entire building, and particularly the cloister, has been the object of a number of restorations over the centuries, as well as a significant conservation endeavour conducted between 2000 and 2003. In the in-depth diagnostic survey undertaken on that occasion, the composition and morphology of the plaster in both interiors and exteriors were determined to obtain further insight into the history of the cloister and its conservation. Plaster representative of the various phases of construction were characterized with techniques such as powder $X$-ray diffraction, mercury intrusion porosimetry, thin section optical microscopy and atomic spectrometry. As a result of these analyses, groups of samples with similar characteristics could be identified, confirming historiographic hypotheses on the sequence of the restoration and conservation work done on the building and establishing a possible tool for architectural archaeology.

Keywords: plaster classification, architectural archaeology, St Abbondio Cloister (Como), historic plaster.

(*) CNR - ICVBC - Sezione 'Gino Bozza', Milano (Italia).

(**) Dipartimento BEST, Politecnico di Milano (Italia).

(***) Dipartimento di Scienze Chimiche e Ambientali, Università degli Studi dell'Insubria, Como (Italia). 


\section{INTRODUCCIÓN}

Sant'Abbondio, localizada en Como (Italia), es una abadía construida en el periodo románico sobre las ruinas de una iglesia paleocristiana con planta en cruz latina. El monumento representa una de las obras maestras del estilo románico después de los pesados trabajos de reconstrucción y reintegración que se ejecutaron entre los siglos XIX y XX.

El claustro muestra una arquitectura del siglo XVI aunque fue parcialmente reconstruido en el siglo XIX. Recientemente ha sido objeto de un completo trabajo de conservación y en esta ocasión se ha efectuado una vasta campaña analítica de los revoques, tanto internos como externos.

La finalidad de este trabajo ha sido comparar la confrontación entre los revoques extraídos de diferentes partes del edificio para después agruparlos coherentemente. Esta investigación tenía como objetivo confirmar las hipótesis existentes sobre las fases constructivas, las cuales se basaban en datos históricos.

La complejidad del estudio no permite la exclusión de alguna de estas hipótesis, los estudios efectuados con anterioridad nos han proporcionado datos útiles para poder proyectar la campaña de diagnóstico, permitiendo formular las premisas de un modo más eficaz. Las premisas se han enfocado en torno a dos clases de problemas fundamentalmente:

a. Señalar los límites del edificio del siglo XVI y reconocer sus restos;

b. Comprender el aparejo de los muros en las superficies más alteradas, como el caso de la fachada este, para mejorar el proyecto de conservación.

Posteriormente, la atención se ha centrado en la fachada este y en algunos detalles decorativos del segundo y tercer nivel del claustro interno, en algunos ambientes internos y en la escalera principal.

La sobreposición de un cierto número de enlucidos ha sido identificada mediante exploraciones estratigráficas, de esta forma ha sido posible organizar sistemáticamente las conexiones entre los datos encontrados durante los trabajos en el edificio.

El análisis y muestreo de los revoques ha sido atentamente proyectado y encaminado a la clasificación y agrupamiento de las muestras caracterizadas de una composición similar, con la finalidad de verificar las hipótesis acerca de la antigüedad y de las fases constructivas del edificio.

\section{INTRODUCTION}

Sant'Abbondio at Como, Italy, is a Romanesque abbey built over the ruins of a palaeo-Christian cruciform church. The church per se, one of the masterpieces of Italian Romanesque, recovered its original splendour after the considerable reconstruction and refurbishment work performed in the nineteenth and twentieth centuries.

Although partially built in the eighteen hundreds, the earliest part of the cloister exhibits typical sixteenth century architecture. On the occasion of a recent and comprehensive conservation endeavour, an in-depth survey was conducted of the plastering and rendering on interiors and exteriors.

The purpose was to compare and group the plaster samples taken from different parts of the building. The aim of the present study was to confirm existing hypotheses about construction phases based on historical data.

The complexity of the studies suggested that none of these hypotheses should be ruled out. Previous research provided useful data for planning the diagnostic survey and a clearer formulation of the questions to be addressed, which were concerned with essentially two types of problems:

a. To identify the bounds of the sixteenth century building and recognize its remains;

b. To ascertain the texture of the most drastically altered walls, such as the east facade, to improve the conservation design.

Attention subsequently focused on the east facade and some of the decorative details on the second and third storeys of the inner cloister, in some interiors and along the main staircase.

Stratigraphic sampling revealed the existence of a number of layers of plaster, making it possible to systematically interconnect data coincidentally encountered during the works.

Plaster sampling and analysis was carefully planned, and focused on classifying and grouping samples with similar compositions to verify dating and building sequence hypotheses. 
La caracterización de un material compuesto de esta manera necesita ser estudiada con diferentes técnicas analíticas complementarias entre ellas, como se ha detallado ampliamente en la literatura (1-4).

Tradicionalmente los revoques son considerados materiales compuestos, cuyas propiedades estructurales se deben a la adición de una fracción de agregado con una fracción de aglomerante. El aglomerante contribuye principalmente a la trabajabilidad y la elasticidad del producto terminado. El agregado, típicamente arena silícica o carbonática, se utiliza para "rellenar" y controlar la estabilidad dimensional volumétrica.

De este modo, el conocimiento de los revoques históricos, es decir, de los enlucidos producidos hasta el siglo pasado se ha realizado a través de la caracterización de dos fracciones, usando diferentes tipos de análisis.

El objetivo de este trabajo es sugerir una secuencia analítica que tenga como finalidad resolver los problemas de clasificación y de agrupación de las muestras de revoques provenientes de un edificio donde es necesario reconstruir las fases constructivas. Ésta es la intención de los autores cuando se refieren a "Instrumento analítico en arqueología de la arquitectura".

Los datos, en efecto, nos proporcionan algunos criterios para agrupar las muestras con propiedades compositivas similares, que datan presumiblemente del mismo periodo.

\subsection{Notas históricas}

El claustro ha perdido toda evidencia de su forma medieval y se presenta actualmente como un edificio de 3 niveles con arcos y columnas diseñado en el año 1834 por el arquitecto Giuseppe Tazzini para situar el Seminario Diocesano Menor. Un primer estudio de prospección en el claustro ha podido confirmar que una buena parte de éste se date del siglo XVI (5). Nuevos documentos han confirmado que dos lados del claustro han sido construidos a mitad del siglo XVI, mientras solamente el tercer nivel ha sido construido en 1834; un preciario di scalpellini ${ }^{1}$ del 1500 nos ha proporcionado información detallada sobre los elementos arquitectónicos en piedra "Molera" que fueron previstos para dar forma a las fachadas revocadas y que fueron casi todas removidas por Tazzini. La forma original de los otros dos lados, enteramente construidos por Tazzini, es desconocida, uno de los problemas que se debía resolver era encontrar los límites del edificio renacentista, principalmente en el lado este.

Evaluando el mecenismo de los miembros de la familia Castiglioni (provenientes de Castiglioni Olona, considerado como uno de los mayores centros de cultura renascentista
Materials with such a complex composition must be studied with a number of complementary analytical techniques, as widely sustained in the literature (1-4).

Plaster is traditionally regarded to be a composite material that owes its structural properties to the mixture of aggregates and binder. The binder contributes essentially to the workability and elasticity of the finished product. The aggregate, typically siliceous or calcareous sand, is used as a filler and to control shrinkage.

Consequently, the determination of the composition of historic plaster, i.e., pre-twentieth century rendering material, involves the use of different analytical techniques to characterize these two fractions.

The purpose of the present paper is to suggest an order for conducting such analyses to solve the problems arising in the classification and grouping of plaster samples from a building where the construction sequence has to be reconstructed. This is the intention underlying the phrase "analytical tool for architectural archaeology".

The findings, in fact, yielded criteria for grouping samples with similar compositional properties that presumably date from the same period.

\subsection{Historic notes}

The cloister, devoid of any vestige of its Medieval origins, presently constitutes a three-storey arch and column building designed by architect Giuseppe Tazzini in 1834 to house the Lower Diocesan Seminary. An initial inspection of the cloister revealed that much of the building dates back to the sixteenth century (5). New documents confirmed that two sides of the cloister had been built by the mid-sixteenth century, with only a third storey added in 1834; a price list for stone-cutters ${ }^{1}$ from the $1500 \mathrm{~s}$ provides detailed information on the architectural elements in "Molera" stone commissioned as supports for the rendered facades and almost completely demolished by Tazzini. Since there is no historical evidence about the original shape of the two sides built by Tazzini, one of the problems to be solved was to establish the limits of the Renaissance building, particularly on the east side.

A review of the Castiglioni family's (from Castiglioni Olona, one of the hubs of Renaissance culture in northern Italy) patronage of the arts, in conjunction with a study 
del norte de Italia) y estudiando los detalles arquitectónicos (donde podemos encontrar bases dóricas a "toro singolo e gola", similares a los del claustro dórico de S. Ambroggio en Milán), es ahora cuando es posible asegurar que el claustro de S. Abbondio en Como puede ser importante para reconstruir las líneas de arquitectura lombarda, construida o proyectada después de la actividad de Bramante en Lombardía.

La alcaldía de Como adquirió el claustro en 1974 e inmediatamente se ejecutaron los trabajos de consolidación. En una primera etapa se intervino sobre la cimentación y, por último, sobre la estructura entera de los muros y las bóvedas.

\section{PARTE EXPERIMENTAL}

Por cuanto concierne al caso de estudio del claustro de S. Abbondio, las muestras de los revoques han sido seleccionados de los elementos arquitectónicos que pueden ser identificados como del periodo románico, renacentista o del siglo XIX y confrontados entre ellos desde el punto de vista morfológico, químico y físico. Los enlucidos muestran un espesor variable entre 2 a $6 \mathrm{~cm}$; los muros han sido construidos con bloques de piedra de Montralsio ${ }^{2}$ escuadrados sin mucho cuidado, que, en algunos puntos, están integrados con ladrillo. Han sido investigados tanto los estratos de los acabados como las estratigrafías de los revoques.

Las muestras han sido caracterizadas por difracción de rayos $\mathrm{X}$ en polvo, porosimetría por intrusión de mercurio, microscopía óptica y espectrometría atómica. La difracción de rayos $X$ en polvo (XRD) y la observación de secciones finas con microscopio petrográfico han permitido identificar la naturaleza de las fases mineralógicas presentes en las muestras (4, 7-9), mientras las informaciones estructurales han sido obtenidas de los análisis porosimétricos (1). Adicionales datos sobre la composición pueden ser obtenidos a través de los análisis del contenido en metales tras la disolución ácida de la muestra (11-14) [principalmente calcio y magnesio, representativos de la fracción relativa al conglomerante aéreo y silico; hierro y aluminio característicos tanto de la fracción hidráulica como del agregado $(4,10)]$.

\section{Análisis porosimétrico}

Los análisis han sido efectuados sobre muestras cúbicas de $1 \mathrm{~cm}$ de lado, empleando un porosímetro de intrusión de mercurio Thermoquest Pascal 240; determinando los macroporos con radio comprendido entre 7,5 y $3,7 \times 10^{-3} \mathrm{~mm}$ y Pascal 140 para megaporos con radio $>7,5 \times 10^{-3} \mathrm{~mm}$. Mega y macroporos han sido definidos segun la clasificación IUPAC. of the architectural details (with "toro singolo e gola" Doric bases similar to the ones in the St Ambroggio Doric Cloister at Milan), suffices to assert that the St Abbondio Cloister at Como may be relevant to the reconstruction of the lines of Lombard architecture erected or designed after Bramante's activities in Milan.

The Como Town Hall purchased the cloister in 1974 and immediately undertook rehabilitation work, initially to restore the foundations and subsequently the entire structure, including walls and domes.

\section{EXPERIMENTAL}

The samples taken in the St Abbondio cloister were extracted from architectural elements identified as Romanesque, Renaissance or nineteenth century, and compared for morphological, chemical and physical properties. The plaster layers varied in thickness from 2 to $6 \mathrm{~cm}$; the underlying masonry consisted in with rather roughly hewn Montralsio ${ }^{2}$ stone ashlars, supplemented in some cases with brick. All the plaster coats -rendering, floating and setting-were analyzed.

Samples were characterized using powder X-ray diffraction, mercury intrusion porosimetry, optical microscopy and atomic spectrometry. The nature of the mineralogical phases in the samples was identified with powder $X R D$ and the observation of thin sections with a petrographic microscope (4, 7-9), while structural information was obtained from the porosimetric analyses (1). Subsequent compositional details could be deduced from metal content testing [primarily calcium and magnesium, representative of the binder fraction, and silicon, iron and aluminium characteristic of both the hydraulic fraction and the aggregate $(4,10)$ after dissolving the sample in acid (11-14)].

\section{Porosimetric analysis}

The analyses were conducted on 1-cm cubic specimens with a Pascal 240 Thermoquest mercury porosimeter to determine the macropores with radii ranging from 7.5 to $3.7 \times 10^{-3} \mathrm{~mm}$ and a Pascal 140 device to determine megapores with radii of over $>7.5 \times 10^{-3} \mathrm{~mm}$. Mega and macropores were defined as set out in the IUPAC classification. 


\section{Análisis petrográfico}

Las secciones finas de las muestras han sido observadas usando un microscopio Zeiss Standard con luz polarizada.

\section{Difracción de rayos $X$ en polvo}

Las muestras de polvo han sido analizadas utilizando un difractor Philips PW 1130-90 equipado con un goniómetro PW $1050-28$ de $3^{\circ}$ a $65^{\circ} 2 \theta$, velocidad de paso de $0,02^{\circ} 2 \theta$ y 1 segundo de tiempo continuo, usando radiación CuK $\alpha$, en condiciones del tubo $40 \mathrm{kV}$ y $20 \mu \mathrm{A}$. Las muestras de polvo han sido colocadas en contenedores de aluminio Al o en un portamuestras de vidrio, en función a la cantidad de la muestra a disposición. La fracción de aglomerante y la de agregado han sido previamente separadas mecánicamente.

\section{Análisis elemental}

El ataque ácido ha sido efectuado como sigue a continuación: una cantidad pesada de muestra seca ha sido tratada con $\mathrm{HCL} 1 \mathrm{~N}$ en agua ultrapura. La suspención se ha agitado a temperatura ambiente por dos horas y filtrada con un filtro en fibra de vidrio $(0,25 \mu \mathrm{m})$; el residuo ha sido cuidadosamente lavado y pesado, posteriormente la solución ha sido analizada. Hierro y aluminio han sido identificados con la espectrometría atómica de absorbimiento con atomización electrotérmica (ETAAAS), mientras que el silicio, calcio, magnesio han sido identificados mediante "Inductively Coupled PlasmaOptical Emission Spectroscopy" (ICP-OES). Las líneas analíticas usadas para la determinación ET-AAS han sido $248,3 \mathrm{~nm}$ para el hierro y $309,3 \mathrm{~nm}$ para el aluminio. Las líneas espectrales ICP-OES han sido $393,366 \mathrm{~nm}$ para el calcio, $279,533 \mathrm{~nm}$ para el magnesio y $252,411 \mathrm{~nm}$ para el silicio.

\subsection{Muestreo de los revoques}

Los revoques han sido extraídos por medio de escalpelo y bisturí (15). La Tabla 1 muestra una breve descripción y el área de procedencia de las muestras. En cuanto a las muestras de la 1 a la 6, la procedencia se muestra también en las Figuras 1 y 2 .

El muestreo ha sido focalizado teniendo en cuenta algunas características del edificio, en las galerías al segundo nivel (muestras 1-3) y del tercer nivel del claustro (muestras 4-6). En lo concerniente a las fachadas externas, ha sido objeto de análisis sólo la fachada este.

La elección de la ubicación de las muestras se ha basado en la evaluación de la documentación histórica y el análisis de la morfología del edificio (16). La documentación histórica revela que los revestimientos de las bóvedas

\section{Petrographic analysis}

Thin sections of samples were observed with a standard Zeiss microscope under polarized light.

\section{$X$-ray diffraction}

Powder samples were analyzed with a Philips PW 113090 diffractometer fitted with a PW 1050-28 goniometer, using a $2 \theta$ angle range of from $3^{\circ}$ to $65^{\circ}$, a step size of $0.02^{\circ}$ and a count time per step of one second, under CuKa radiation; tube conditions were $40 \mathrm{kV}$ and $20 \mu \mathrm{A}$. The powder samples were pressed on to aluminium pellets or glass slides, depending on the amount of sample available. The binder and aggregate fractions were separated mechanically prior to analysis.

\section{Compositional analysis}

The samples were attacked with acid as follows: a weighed dry sample was treated with $1 \mathrm{~N} \mathrm{HCl}$ in laboratory grade water. The suspension was stirred at ambient room temperature for two hours and filtered through a $(0.25-\mu \mathrm{m})$ fibreglass filter, after which the residue was carefully washed and weighed and the solution analyzed. Iron and aluminium were detected with electrothermal atomization atomic absorption spectrometry (ETA-AAS), while inductively coupled plasma-optical emission spectroscopy (ICP-OES) was used to identify silicon, calcium and magnesium. The ETA-AAS absorption lines used were $248.3 \mathrm{~nm}$ for iron and $309.3 \mathrm{~nm}$ for aluminium. The ICP-OES spectral lines adopted were $393.366 \mathrm{~nm}$ for calcium, 279.533 for magnesium and 252.411 for silicon.

\subsection{Plaster sampling}

Plaster samples were taken with scalpels (15). Table 1 gives a brief description and the origin of the samples. The origin of samples 1 through 6 is also shown in Figures 1 and 2 .

Sampling focused on certain characteristics of the building located in the walkways on the second (samples 13) and third storeys (samples 4-6) of the cloister. The facade itself was only sampled on the east side.

Samples were chosen based on a review of the historic documentation and an analysis of the building morphology, conducted in a previous stage (16). According to the historical documents, the vaults 
(muestra 3) han sido aplicados durante el siglo XVI, mientras que los revoques de los muros (muestras 1, 2, 4, 7, 8) probablemente datan del siglo XIX.

A modo particular la fachada este, que se desarrolla en más de 47 metros de largo, ha sido objeto de importantes trabajos de reconstrucción que han aumentado la complejidad de la estratigrafía de los revoques. En esta superficie aparecen muchas islas de revoque "martellato" 3 bajo un estrato uniforme de color gris. El muestreo ha sido realizado a través de diferentes exploraciones estratigráficas efectuadas en todo el edificio, con la finalidad de reducir el impacto del mismo.

\section{RESULTADOS Y DISCUSIÓN}

Los resultados de la investigación petrográfica, porosimétrica y difractométrica han sido resumidos en la Tabla 2. Por cuanto concierne a las características mineralógicas, morfológicas y fisicas, las muestras han sido agrupadas según el siguiente esquema (Figura 1): (sample 3) were plastered in the sixteenth century, while the wall plaster (samples 1, 2, 4, 7, 8) probably dates from the nineteenth.

Layer stratigraphy was particularly complex on the 47metre long east facade, which had been the object of significant reconstruction. There are many pockets of hammer-roughened plaster or "martellato"3 on this surface, under a uniform grey layer. Numerous stratigraphic surveys were conducted to identify areas for sampling, in an attempt to reduce the impact on the building.

\section{RESULTS AND DISCUSSION}

The results of the petrographic, porosimetric and XRD analyses are summarized in Table 2. The samples were grouped according to the scheme set out below (Figure 1) on the grounds of their mineralogical, morphological and physical properties:

Tabla 1 / Table 1

Descripción de las muestras de revoques y su localización en el edificio

Description and building location of the samples of plasters

\begin{tabular}{|c|c|c|c|}
\hline $\begin{array}{l}\text { Muestra } \\
\text { Sample }\end{array}$ & $\begin{array}{l}\text { Descripción y área de procedencia } \\
\text { Description and origin }\end{array}$ & $\begin{array}{l}\text { Muestra } \\
\text { Sample }\end{array}$ & $\begin{array}{l}\text { Descripción y área de procedencia } \\
\text { Description and origin }\end{array}$ \\
\hline 1 & $\begin{array}{l}\text { Revoque blanco de una pared bajo el nivel actual } \\
\text { de la pavimentación } \\
\text { White wall plaster below the present floor level }\end{array}$ & 6 & $\begin{array}{l}\text { Revoque "alisado" de una pared, más arriba que la muestra 5: } \\
\text { aparejo poco fino y grumos blancos difusos } \\
\text { "Smooth" wall plaster, higher up than in sample 5; rough } \\
\text { texture with white lumps throughout }\end{array}$ \\
\hline $2 a$ & $\begin{array}{l}\text { Revoque rosado de una pared detrás de una viga en cemento } \\
\text { Pinkish wall plaster behind a cement beam }\end{array}$ & $7 \mathrm{7a}$ & $\begin{array}{l}\text { Revoque de la fachada este externa; muestra recogida } \\
\text { del estrato inferior "martellato" } \\
\text { Outer east facade plaster; sample taken from the rough inner } \\
\text { layer ("martellato") }\end{array}$ \\
\hline $2 b$ & $\begin{array}{l}\text { Revoque de una pared, en la misma posición del 2a, } 1 \text { metro } \\
\text { más alto y más a la derecha } \\
\text { Wall plaster, same general position as sample 2a, } 1 \text { metre } \\
\text { higher and to the right }\end{array}$ & $7 b$ & $\begin{array}{l}\text { Revoque de la fachada este externa; muestra recogida } \\
\text { del estrato superior "alisado" } \\
\text { Outer east facade plaster; sample taken from the outer layer } \\
\text { "alisado" }\end{array}$ \\
\hline $2 c$ & $\begin{array}{l}\text { Revoque de una pared, en la misma posición del } 2 \mathrm{~b} \\
\text { a un nivel inferior } \\
\text { Wall plaster, same general position as sample } 2 b, \\
\text { at a lower level }\end{array}$ & $8 a$ & $\begin{array}{l}\text { Revoque de la fachada este externa; muestra recogida } \\
\text { del estrato inferior "martellato" } \\
\text { Outer east facade plaster; sample taken from the rough inner } \\
\text { layer ("martellato") }\end{array}$ \\
\hline 3 & $\begin{array}{l}\text { Revoque de la bóveda de la ménsula } \\
\text { Plaster from the corbel vault }\end{array}$ & $8 b$ & $\begin{array}{l}\text { Revoque de la fachada este externa; muestra recogida } \\
\text { del estrato superior "alisado" } \\
\text { Outer east facade plaster; sample taken from the "smooth" } \\
\text { outer layer alisado" }\end{array}$ \\
\hline 4 & $\begin{array}{l}\text { Revoque de una pared con muchos estratos de pinturas } \\
\text { de colores } \\
\text { Plaster from a wall with many layers of different colour paint }\end{array}$ & $9 a$ & $\begin{array}{l}\text { Revoque de la fachada este externa; muestra recogida } \\
\text { del estrato inferior "martellato" } \\
\text { Outer east facade plaster; sample taken from the rough inner } \\
\text { layer ("martellato") }\end{array}$ \\
\hline 5 & $\begin{array}{l}\text { Revoque de una pared "martellato", vecino a la muestra } 4 \\
\text { Hammer-roughened wall plaster, adjacent to sample } 4\end{array}$ & $10 a$ & $\begin{array}{l}\text { Revoque de la fachada este externa; muestra recogida } \\
\text { del estrato inferior "martellato" } \\
\text { Outer east facade plaster; sample taken from the rough inner } \\
\text { layer ("martellato") }\end{array}$ \\
\hline
\end{tabular}


- grupo $1(1,2 a, 2 b, 2 c$ estrato interno, 4);

- grupo 2 (2c estrato externo);

- grupo 3 (3);

- grupo 4 (5, 7a, 8a, 9a, 10a);

- grupo 5 (6);

- grupo 6 (7b, 8b).

El aglomerante no ha resultado particularmente útil para clasificar las muestras, porque todas contienen el mismo, es decir, que todas las muestras presentan como aglomerante la cal. Al contrario, la composición del agregado ha resultado útil para separar el grupo 1 (composición silicática) y el grupo 2 (composición calcárea) de los otros grupos caracterizados por una composición mixta.

La arena utilizada como agregado del revoque muestra diferentes procedencias en función de su composición: arena silícica procedente del fondo del río Adda en la parte norte del lago de Como (afloramiento de rocas ígneas y metamórficas); arena de composición mixta procedentes de sedimentos situados en la parte sur del
- group 1 (1, 2a, 2b, inner layer of 2c,4);

- group 2 (outer layer of 2c);

- group 3 (3);

- group 4 (5,7a, 8a, 9a, 10a);

- group 5 (6);

- group $6(7 b, 8 b)$;

The binder was not particularly useful for classifying the samples, for they were all made with lime. Aggregate composition, on the contrary, proved to be useful to separate groups 1 (siliceous) and 2 (calcareous) from the other groups, whose composition was found to be mixed.

The divergent composition of the sand used in the plaster coatings is indicative of different origins: siliceous sand from the bottom of the Adda River north of Lake Como (outcrops of igneous and metamorphic rocks) and mixed sand from sediments in the southern side of the lake (glacial-fluvial deposits and calcareous outcrops)
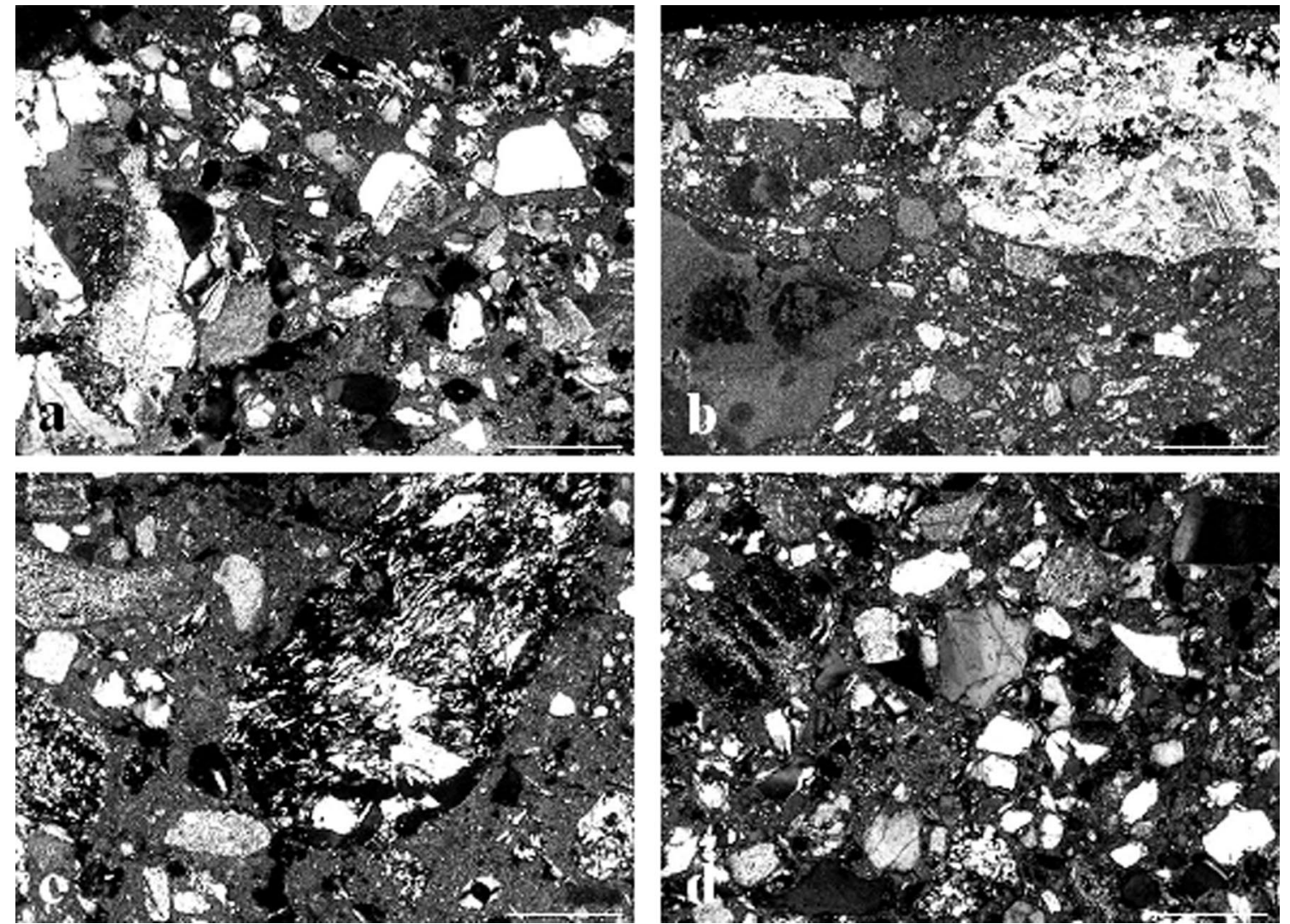

Figura 1. Observación en la sección fina de una muestra del grupo 1 (a, muestra 1), 2 (b, muestra 2c), 4 (c, muestra 7a), 6 (d, muestra 8b). Se observan diferencias en las composiciones mineralógicas, tamaño de los granos y disposición del agregado del revoque. Generalmente la morfología de los granos muestra baja esfericidad y esquinas semirredondeadas.

Figure 1. Thin sections for samples in group 1 (a, sample 1), 2 (b, sample 2c), 4 (c, sample 7a), and 6 (d, sample 8b). The mineralogical composition, as well as grain size and arrangements, differ in the various plaster aggregates. As a rule, grain morphology is only slightly spherical with semi-rounded corners. 
Tabla 2 / Table 2

Tabla sinóptica de los resultados DRX y del análisis porosimétrico de los estudios petrográficos Synoptic table of XRD and porosimetric results and of petrographic studies

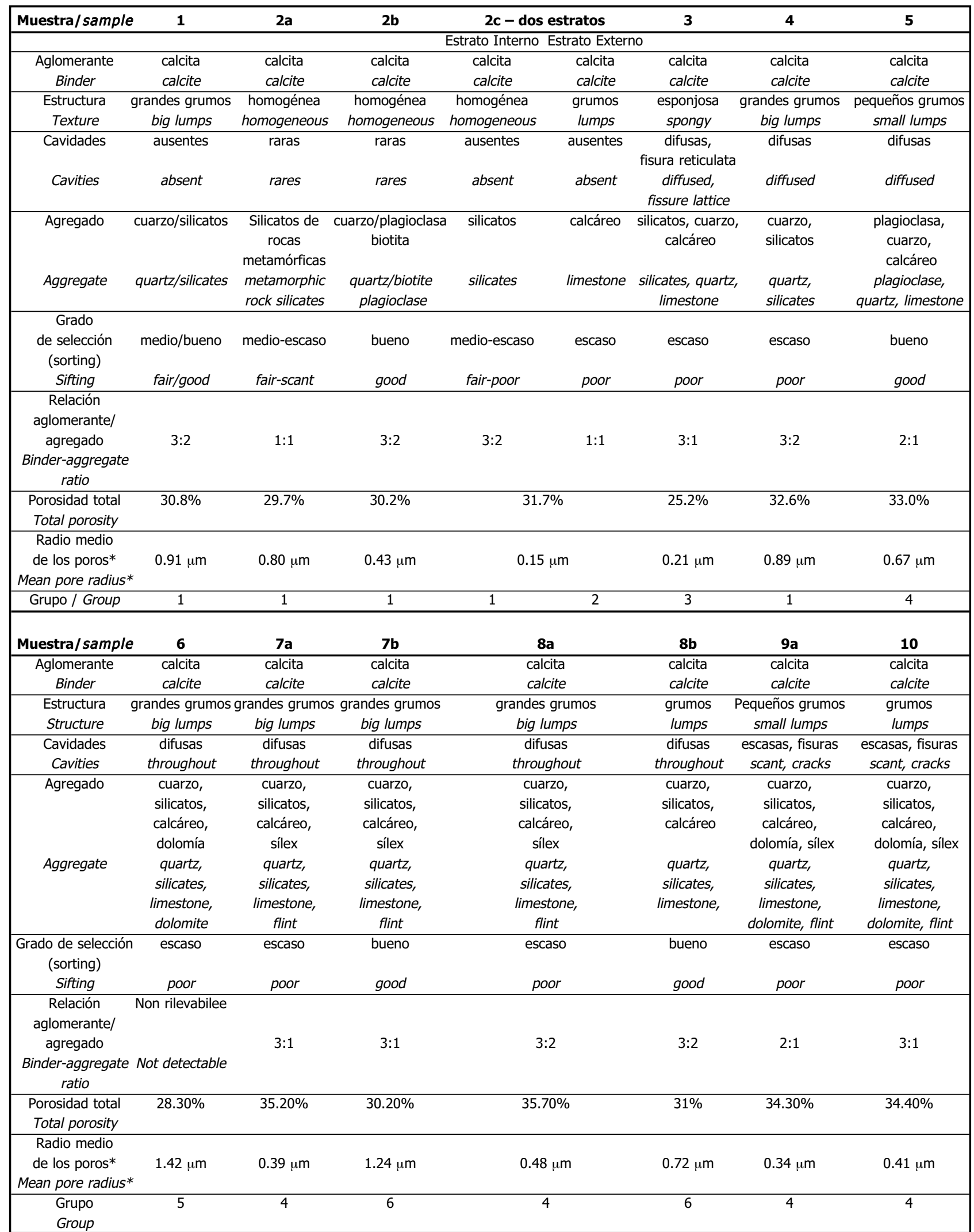

* El radio medio de los poros representa la media de los poros calculada al 50\% (radio de los poros al volumen acumulativo de mercurio máximo/2).

* The mean pore radius is the $50 \%$ mean (pore radius at maximum cumulative volume of mercury/2). 
lago (depósitos glaceofluviales y afloramientos calcáreos) (16). La arena calcárea ha sido particularmente seleccionada para el estrato externo del revoque siguiendo con la receta de Vitruvio. La relación aglomerante/agregado va de $1: 1$ a $3: 1$ y no ha sido considerada útil como parámetro para agrupar las muestras; de todos modos esta relación respeta la receta utilizada en los antiguos tratados de construcción.

El único grupo que ha mostrado una clara variedad entre los grupos examinados es el grupo 6, que está formado por muestras localizadas en la parte más externa de la estratigrafía, quiere decir que éstas representan un recubrimiento aplicado en tiempos recientes cuando se disponía de mejor tecnología para la separación selectiva. Como se muestra en la Tabla 2, el grupo 1 está caracterizado por una elevada densidad. La muestra 3 es la única que presenta cavidades con forma de fisuras. La estructura ha sido eficaz en distinguir el grupo 3 porque éste muestra características esponjosas.

Los valores de porosidad total son homogéneos para el grupo 1 y grupo 2 . La porosidad abierta total es particularmente útil para distinguir entre el grupo 4 (del $34,3 \%$ al $35,7 \%), 5(28,3 \%)$ y 6 (del $30,2 \%$ al $31 \%$, que han sido elaborados con el mismo agregado mixto. El radio medio de los poros confirma la agrupación descrita.

La identificación de los metales se ha efectuado sólo cuando la cantidad de las muestras (denominadas 1, 6, $7 a, 8 a, 9 a$ y 10) permitía la aplicación del complejo e invasivo proceso de ataque ácido. La composición en términos de porcentaje en peso de especie y de residuo
(16). The calcareous sand was specially selected for the outer finish, in keeping with the Vitruvius method. The binder/aggregate ratio, which ranged from 1:1 to 3:1, was not regarded to be a useful parameter for grouping the samples, for these ratios are within the interval specified in historic building treatises.

Of all the groups, only the sixth, consisting of samples located on the outer-most layer -i.e., a covering applied in more recent times when better screening technology was available- exhibited good sifting. As Table 2 shows, group 1 is characterized by high density 4 . Sample 3 is the only one with crack-like cavities. Structure was helpful to distinguish group 3, which exhibited spongy characteristics.

The total porosity values are uniform in groups 1 and 2 . Total open porosity is particularly useful to distinguish among groups 4 (from $34.3 \%$ to $35.7 \%$ ), 5 (28.3\%) and 6 (from $30.2 \%$ to $31 \%$ ), all of which contained the same mixed aggregate. Mean pore radius confirmed the grouping described.

Metals were identified only for those samples $(1,6,7 a$, $8 a, 9 a$ and 10) for which there was sufficient material to conduct the complex and invasive acid attack procedure. The composition in percentage by weight of species and residue after the acid attack was similar in all the samples

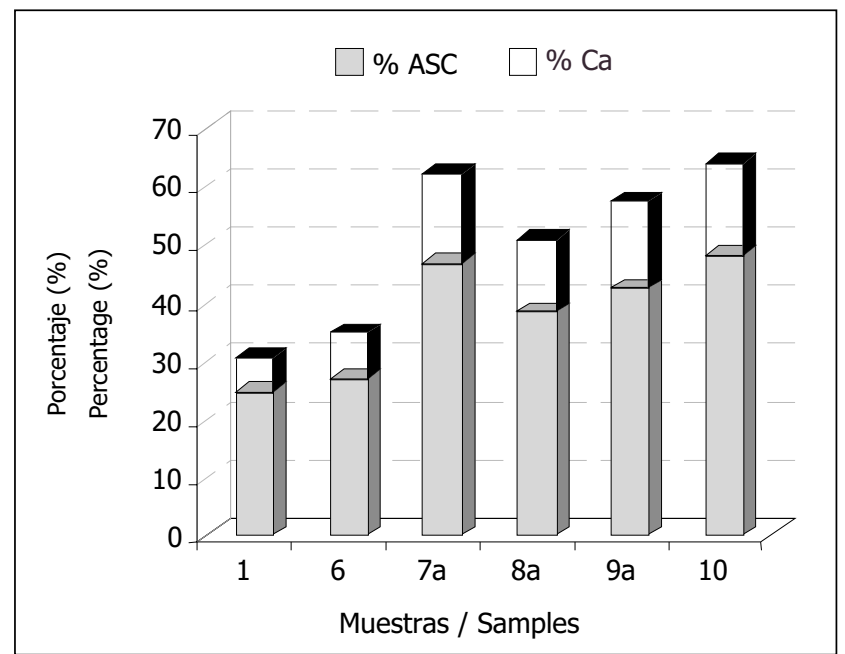

Figura 2. Contenido de calcio (\% Ca, porcentual en peso) y fracción soluble en ácido (\% ASC, porcentual en peso) de las muestras de revoque.

Figure 2. Calcium content (\% Ca by wt) and acid-soluble content (ASC, \% by wt) of plaster samples. 
después del ataque ácido es similar en todas las muestras analizadas, excepto para el contenido de calcio. Las muestras 1 y 6 han mostrado porcentajes de calcio más bajos respecto a las otras muestras, como se ilustra claramente en el histograma de la Figura 2.

El porcentaje de la fracción soluble en ácido (\%ASC) de las muestras ha seguido la misma tendencia observada para el contenido de calcio (Figura 2).

El porcentaje ASC ha sido calculado con la siguiente fórmula [1]: analyzed, with the exception of calcium content. Samples 1 and 6 had lower percentages of calcium than the others, as the histogram in Figure 2 clearly shows.

The percentage of acid-soluble content (\% ASC), which followed the same pattern as identified for calcium content (Figure 2).

Was calculated from the following expression [1]:

$$
\% \text { ASC }=100\left(W_{m}-W_{a}\right) / W_{m}
$$

donde $W_{m}$ es el peso de la muestra de revoque secado y $W_{a}$ el peso del residuo después de la disolución ácida y lavado (14).

La composición de los metales muestra claramente la diferencia entre las muestras de revoque analizados y se han podido clasificar en dos grupos distintos: las muestras $8 a, 9 a, 10$ e $7 a$ en un grupo y las muestras 1 y 6 en otro, confirmando la clasificación mostrada en la Tabla 2, mencionada anteriormente.

\section{CONCLUSIONES}

Se ha aplicado una secuencia analítica a las muestras de revoques históricos provenientes del claustro de $\mathrm{S}$. Abbondio y a aquéllas que representan a las diferentes fases constructivas del edificio. Se han utilizado distintas técnicas complementarias con la finalidad de definir la composición de las muestras, la cual viene a considerarse como un soporte válido cognoscitivo para programar los trabajos de conservación.

La secuencia de las fases constructivas sugerida por los datos históricos ha sido, en efecto, confirmada por los resultados de la investigación química y minerológica, que han permitido agrupar las muestras que presentaban una composición similar, las cuales se ha demostrado que corresponden a una idéntica fase constructiva y tecnológica. En particular, ha sido puesto en evidencia que la fachada del edificio presenta amplias áreas de revoques pertenecientes al siglo XVI, mientras que las paredes internas del patio han sido probablemente privadas de su enlucido original en el siglo XIX.

Los resultados analíticos han confirmado que la naturaleza químico/minerológica del agregado es un potente instrumento para clasificar las muestras de revoques. Al contrario, las características químicas del conglomerante no han resultado particularmente útiles, al menos en where $W_{m}$ is the dry weight of the plaster sample and $W_{a}$ the weight of the residue after dissolution in acid and washing (14).

The clear distinction drawn among the plaster samples in terms of metal content led to the establishment of the following groups: samples 8a, 9a, 10 and 7a formed one group and samples 1 and 6 another, confirming the classification given in Table 2 above.

\section{CONCLUSIONS}

Samples of historic plaster from the St Abbondio Cloister representative of the different construction phases of the building were sequenced on the basis of analytical data. Different complementary techniques were used to define sample composition, information regarded to be instrumental for conservation planning.

The sequence of the construction phases suggested by historical data was confirmed by the results of the chemical and mineralogical tests. These findings were used as grounds for grouping samples, on the assumption that materials with similar compositions were from the same construction and technological period. Specifically, large sections of the building's facade were shown to still bear sixteenth century rendering, while the inside courtyard walls were very likely stripped of their original plastering in the nineteenth century.

The analytical results showed that the chemical/mineralogical nature of the aggregate is a powerful tool for classifying plaster samples. The chemical characteristics of the binder, by contrast, were not found to be particularly useful, at least in the present case: since plaster was 
este caso, porque, en cuanto concierne a los revoques antiguos, éstos eran fabricados casi siempre con la cal. Por esta razón, analizando esta característica, las muestras que provienen de un edificio antiguo son difícilmente diferenciables.

Por lo que corresponde a la relación entre el aglomerante y el agregado, los autores consideran que esto no es particularmente útil a fin de distinguir entre las muestras, por la misma razón antes expuesta sobre la composición química del aglomerante, pues su valor varía normalmente en un intervalo demasiado reducido, que no es lo suficientemente específico para diferenciar las muestras.

Al contrario, tanto la estructura como el grado de selección (sorting), se han demostrado como instrumentos útiles para agrupar las muestras de acuerdo a la tecnología de cernido y a las características morfológicas.

El porcentaje de calcio y de fracción soluble en ácido (\% ASC), obtenidos después de la disolución ácida de las muestras y el análisis del contenido en metales, han aportado una posterior herramienta de clasificación, confirmando la basada en el análisis mineralógico anteriormente mencionado.

Teniendo en cuenta los resultados de la campaña de diagnóstico, los autores sugieren que los trabajos de conservación sean compatibles, más desde el punto de vista estético que conservativo y que se utilice un revoque con composición, granulometría y tonalidad cromática similar al original que existe actualmente en la obra.

Se sugirió finalmente que la pintura utilizada sea a base de silicato de potasio. Pinturas con silicatos deberían ser las preferidas a causa de su buen comportamiento cuando están expuestas a los agentes atmosféricos, en particular en lo que concierne a la pérdida del color, considerando la dimensión y la exposición de las paredes externas del claustro. always made with lime in those periods, on the basis of the analysis of this property, samples from a historic building are scarcely distinguishable.

The binder/aggregate ratio is not regarded to be especially helpful for differentiating samples, either, for a similar reason, for the value fluctuates within too narrow a range to constitute a distinguishing characteristic.

On the contrary, both structure and sifting proved to be useful tools for grouping samples on the basis of screening technology and morphological characteristics.

The percentage of calcium and acid-soluble content (\% ASC) obtained after dissolving the samples in acid and analyzing the metal content provided another classification criterion which, moreover, confirmed the results of the mineralogical analysis.

In light of the diagnostic survey findings, it is felt that conservation works should be compatible from the aesthetic and conservation standpoints and that the plaster/rendering used should be similar in composition, particle size distribution and colour to the material in place.

Finally, a potassium silicate-base paint should be used. Silica paints are preferred for their good weathering performance, particularly as regards fading, given the size and exposure of the outdoor walls of the cloister.

\section{NOTAS/NOTES}

\footnotetext{
1 Artesanos que trabajaban la piedra, deriva del nombre del instrumento que utilizaban llamado Scalpello (trad. escalpelo) / Craftsmen who worked stones by means of a tool called "Scalpello".

2 Piedra calcárea local / Local limestone.

3 "Martellato" (trad. martillado) es el procedimiento por el cual se martillaba el revoque antiguo para crear una superficie rugosa que aseguraba una mayor adhesión al revoque de nueva aplicación / "Martellato" is the ancient process of hammering plasters in order to create a rough surface for a stronger grip of new mortars
} 


\section{BIBLIOGRAFÍA/BIBLIOGRAPHY}

(1) Alessandrini, G.: Gli intonaci nell'edilizia storica: metodologie analitiche per la caratterizzazione chimica e fisica, Atti del Convegno di Studi 'Scienza e Beni Culturali - L'intonaco: storia, cultura e tecnologia', Bressanone, Italy (1985), pp. 147-166.

(2) Moropoulou, A., Bakolas, A. Bisbikou, K.: "Investigation of the technology of historic mortars", Journal of Cultural Heritage, n. 1 (2000), pp. 45-58.

(3) Paama, L., Pitkanen, I., Peramaki, P.: "Thermal and infrared spectroscopic characterisation of historical mortars", Thermochimica Acta, n. 320 (1998), pp. 127-133.

(4) Álvarez de Buergo, M.; Fort, R.; Gómez-Heras, M.: "The Monastery of Ucles (Cuenca, Spain): characterisation and deterioration of building materials", Mater. Construcc., n. 275 (2004), pp. 5-22.

(5) Della Torre, S.: Note sul chiostro di S. Abbondio, in S. Abbondio lo spazio e il tempo. Tradizione storica e recupero architettonico, Exhibition Catalogue, Como, Italy (1984), pp. 309-326.

(6) Della Torre, S.: Il cantiere della Cattedrale e l'architettura del Rinascimento a Como, in Le arti nella diocesi di Como durante i vescovi Trivulzio, Proceedings edited by M. L. Casati e D. Pescarmona, Como, Italy (1998), pp. 23-33.

(7) Fernández Rodríguez, J. M., Fernández Fernández, J. A.: "Physical-chemical characterization of roman mortars in El Ruedo at Almedinilla, Córdoba", Mater. Construcc., n. 275 (2004), pp. 39-51.

(8) Gulec, A., Tulun, T.: "Physico-chemical and petrographical studies of old mortars and plasters of Anatolia", Cem. Concr. Res., n. 27 (1997), pp. 227-234.

(9) Antonelli, F., Cancelliere, S., Lazzarini, L.: "Minero-petrographic characterisation of historic bricks in the Arsenale, Vence", Journal of Cultural Heritage, n. 3 (2002), pp. 59-64.

(10) Manzano, E., Bueno, A. G., Gonzales-Casado, A., del Olmo, M.: "Mortars, pigments and binding media of wall paintings in the "Carrera del Darro" in Granada, Spain", Journal of Cultural Heritage, n. 1 (2000), pp. 19-28.

(11) Álvarez, J. I., Martín, A., García Casado, P. J., Navarro, I., Zornoza, A.: "Methodology and validation of a hot hydrochloric acid attack for the characterization of ancient mortars", Cem. Concr. Res., n. 29 (1999), pp. 1061-1065.

(12) Charola, A. E., Dupas, M., Sheryll, R. P., Freund, G. G.: Characterization of ancient mortars: chemical and instrumental methods. Proceedings of the Symposium Scientific Methodologies applied to Works of Art, Firenze, Italy (198), pp. 28-33.

(13) Rampazzi, L., Monticelli, D., Verga, R., Toniolo, L.: "A microwave-assisted approach to the chemical analysis of mortars", Annali Chimica (Rome), n. 93 (2003), pp. 315-320.

(14) Dupas, M., Charola, A. E.: A simplified chemical analysis system for the characterization of mortars. Proceedings of the $2^{\text {nd }}$ International Colloquium on Materials Science and Restoration, Esslingen (1986), pp. 309-312.

(15) Raccomandazione Normal 3/80 "Campionamento" ICR-CNR 1980.

(16) Servizio Geologico Nazionale, Carta geologica della Lombardia, A. Montrasio Publisher, Roma (1990). 